\title{
Pengembangan Prototype Tes Psikologi Perencanaan Karir Siswa SMA
}

\author{
Prototype Development of Career Planing Psychological Test \\ for Senior High School Students
}

\author{
Agam Saka Jati*1, Kusrini ${ }^{2}$, Hanif Al Fatta ${ }^{3}$ \\ 1,2,3 Program Pascasarjana Magister Teknik Informatika Universitas Amikom Yogyakarta \\ Jl Ring road Utara, Condongcatur, Sleman, Yogyakarta 55281 \\ E-mail: *19agamranger@gmail.com, ${ }^{2}$ kusrini@amikom.ac.id, ${ }^{3}$ hanif.a@amikom.ac.id
}

\begin{abstract}
Abstrak
Karir adalah salah satu hal penting yang perlu disiapkan dalam kehidupan seseorang. Perencanaan karir idealnya dilakukan pada masa remaja. Meskipun demikian, banyak siswa SMA masih belum bisa menentukan dan mengambil keputusan tentang pemilihan studi lanjut di Perguruan Tinggi. Lembaga Psikologi DTC membutuhkan pengembangan sistem agar dapat menggantikan peran dari sesi konseling untuk dapat memberikan rekomendasi jurusan kepada siswa yang berasal dari bimbingan belajar yang bekerja sama dengan mereka. Karena keterbatasan tenaga ahli untuk konseling di beberapa kota, maka dibutuhkan pengembangan sistem untuk meningkatkan kualitas pelayanan. Pada penelitian ini, prototype psikotes yang akan dikembangkan adalah tes perencanaan karir. Tes perencanaan karir ini adalah tes model CBT (Computer Base Test) yang berisi tes kognitif (bakat) dan tes minat. Bentuk dari tes kognitif adalah multiple choice menggunakan teori Sternberg. Bentuk dari tes minat adalah forced choice menggunakan teori Holland. Hasil dari prototype ini berupa report yang berisi tentang hasil dari tes kognitif, tes minat dan rekomendasi jurusan yang cocok untuk siswa SMA.
\end{abstract}

Kata Kunci — Sistem Pakar, Psikologi, Kognitif, Minat, Sternberg, Holland.

\begin{abstract}
Career is one of the important things that need to be prepared in a person's life. Career planning is ideally done in adolescence. Even so, many high school students still cannot determine and make decisions about the selection of advanced studies in college. The DTC Psychology Institute requires the development of a system so that it can replace the role of the counseling session to be able to provide recommendations of college majors to students from tutoring agency who collaborate with the DTC. Because of the limited expert for counseling in several cities, it is necessary to develop a system to improve service quality. In this study, the prototype psychological test that will be developed is a career planning test. This career planning test is a Computer Base Tes) model that contains cognitive tests (aptitude) and interest tests. The form of cognitive test is multiple choice using Sternberg's theory. The form of interest test is forced choice using Holland's theory. The results of this prototype is a report containing the results of cognitive tests, interest tests and recommendations of college majors that are suitable for high school students.
\end{abstract}

Keywords - Expert System, Psychology, Cognitive, Interet, Sternberg, Holland. 


\section{PENDAHULUAN}

Masuknya teknologi komputer kedalam ilmu psikologi dapat membantu beberapa pekerjaan manusia. Tidak sedikit yang telah mengembangkan psikotes berbasis komputer. Baik dari tes minat bakat siswa, tes masuk perguruan tinggi, dan lain-lain sesuai dengan kebutuhan masing-masing pengguna atau dalam hal ini sebagian besar adalah perusahaan. Dengan adanya teknologi komputer, maka dapat memangkas waktu, terutama pada saat waktu koreksi dan membuat hasil dari psikotes tersebut.

Pada penelitian ini, psikotes yang dikembangkan adalah psikotes tentang perencanaan karir siswa SMA. Media inputnya akan menggunakan komputer dan hasilnya berupa rekomendasi jurusan diperguruan tinggi berdasarkan profil siswa. Karena psikotes yang telah ada masih menggunakan cara manual dalam koreksinya dan masih membutuhkan seorang psikolog dalam membimbing siswa. Pada cara yang lama, hasil rekomendasi jurusan diperoleh dari tes minat saja, lalu dihubungkan dengan hasil dari kognitif anak pada sesi konseling. Namun ada beberapa kota yang siswanya mengikuti tes ini kesulitan dalam sesi konseling, dikarenakan kurangnya tim psikologi yang ada di kota-kota tersebut.

Psikotes jenis paper based atau manual memerlukan waktu dalam koreksinya. Oleh karena itu, pengembangan yang sering ditemui yaitu pengembangan pada software koreksinya atau pengubahan jawaban ke laporan. Lembar jawab masih dikoreksi secara manual, lalu jawaban dimasukan secara manual ke aplikasi. Sehingga masih membutuhkan waktu yang lebih untuk mengolahnya.

Pada penelitian tentang software tes minat dan bakat pada penerimaan siswa baru di SMK TI Garuda Nusantara Cimahi, penggunaan software berbasis Visual Basic tersebut sangat membantu sekolah untuk dapat menentukan jurusan yan tepat untuk peserta didik baru dengan waktu yang cepat. Perbedaan antara penelitian ini dengan penelitian yang akan dilakukan adalah pada tes bakat yang digunakan tidak jelas menggunakan teori apa dan report yang dihasilkan berbeda (jurusan sekolah kejuruan dengan jurusan perguruan tinggi) [1].

Sistem pakar untuk identifikasi kepribadian siswa menggunakan algoritma fuzzy dapat menutupi masalah kekurangan tenaga pakar. Guru sebagai user dapat memberikan motivasi dan arahan posisitf agar siswa dapat meningkatkan kualitas belajar dan pembentukan karakter serta dapat membantu guru dalam menangani siswa yang perlu diberikan bimbingan dan konseling. Perbedaan antara penelitian ini dengan penelitian yang akan dilakukan adalah perbedaan dasar teori yang dipakai (tes kepribadian dengan tes kognitif dan tes minat) dan penggunaan algoritma fuzzy [2].

Pada sistem pakar bidang psikologi dengan teori MBTI-RMIB, dapat membantu mengetahui karakter siswa dan pemilihan jalur studi siswa berdasarkan minat dan bakat. Hasil yang diperoleh yaitu analisa kepribadian dan prediksi pekerjaan yang cocok sesuai minat dan bakat. Perbedaan antara penelitian ini dengan penelitian yang akan dilakukan adalah dasar teori yang digunakan yaitu teori MBTI-RMIB pada penelitian ini dan teori Stenberg-Holland pada penelitian yang akan dilakukan [3].

Pada rekomendasi sistem penunjang keputusan menggunakan metode simple additive weighting untuk membantu siswa dalam memilih jurusan, menggunakan nilai hasil belajar siswa dan hasil yang muncul berupa daftar rekomendasi jurusan berdasarkan hasil presentasi tertinggi ke terendah. Perbedaan antara penelitian ini dengan penelitian yang akan dilakukan adalah data yang digunakan berasal dari hasil belajar siswa di sekolah, sementara pada penelitian yang akan dilakukan menggunakan hasil dari tes psikologi siswa [4].

Peta minat vokasional siswa sma dan smk di kota salatiga dilakukan untuk mengklasifikasikan siswa sesuai dengan jenis dan minat sekolah dan mengkaitkannya dengan berbagai profesi pekerjaan. Perbedaan antara penelitian ini dengan penelitian yang akan dilakukan adalah penelitian ini hanya menggunakan teori minat Holland saja dan hasil dari penelitian tersebut adalah pemetaan jurusan-jurusan perguruan tinggi (tidak berupa tes yang disajikan kepada siswa) [5]. 
Rancangan sistem pakar psikotes untuk penyeleksian penerimaan karyawan pada STMIK TIME Medan bertujuan untuk mendapatkan karyawan atau tenaga kerja yang lebih berkompeten dalam bidang yang akan dikerjakan sehingga tidak terjadi kesalahan pada penempatan karyawan. Perbedaan penelitian ini dengan penelitian yang dilakukan adalah penelitian ini menggunakan teori atau jenis psikotes PAPI Kostick yang menghasilkan 20 aspek kepribadian, sementara penelitian yang dilakukan menggunakan teori kognitif Stenberg dan teori minat Holland [6].

Perancangan aplikasi tes iq siswa untuk pertimbangan pemilihan jurusan dengan metode forward chaining bertujuan untuk mengevaluasi dan mempercepat pihak sekolah dalam menentukan jurusan yang tepat bagi siswa sesuai dengan kemampuan atau tingkat kecerdasannya. Perbedaan penelitian ini dengan penelitian yang dilakukan adalah penelitian ini lebih mengutamakan potensi/aspek kecerdasan siswa saja yang menghasilkan jurusan di sekolah (IPA/IPS), sedangkan penelitian yang dilakukan menambahkan aspek minat untuk mendukung aspek bakat/kecerdasan siswa dan menghasilkan jurusan untuk perguruan tinggi [7].

Pada penelitian tentang menentukan kecenderungan dan karakter seseorang dengan sistem pakar menggunakan teknik backward chaining menerapkan prinsip experiental learning, peneliti menggunakan kecenderungan seseorang untuk menghasilkan gaya belajar terbaik yang dimiliki seseorang. Perbedaan penelitian ini dengan penelitian yang dilakukan adalah penelitian ini menggunakan teori experiental learning David Kold untuk siklus kecenderungan dan gaya belajar sedangkan penelitian yang dilakukan menggunakan teori kognitif Sternberg dan teori minat Holland [8].

\section{METODE PENELITIAN}

Penelitian ini termasuk dalam jenis penelitian action research atau penelitian tindakan. Penelitian tindakan adalah suatu penelitian dengan melakukan tindakan terhadap suatu kelompok orang atau masyarakat dengan tujuan untuk menjadikan perubahan terhadap situasi, perilaku, dan/atau organisasi, mekanisme kerja, akhir kerja dan sebagainya. Action Research terdiri menjadi 5 tahap, yaitu Diagnosing, Action Planning, Action Taking, evaluating dan Specify Learning.

\subsection{Prototyping}

Prototyping merupakan model pengembangan system yang proses iterative dalam pengembangan sistem dimana requirement diubah ke dalam sistem yang bekerja (working system) yang secara terus menerus diperbaiki melalui kerjasama antara user dan analis. Prototype juga bisa dibangun melalui beberapa tool pengembangan untuk menyederhanakan proses. Dalam metode ini, pengembang dan pelanggan dapat saling berinteraksi selama proses pembuatan sistem.

Sehingga dapat disimpulkan pada Gambar 1 tentang alur penelitiannya, yaitu:

1. Diagnosing: Planning (Studi Literatur dan Identifikasi Masalah).

2. Action Planning: Analysis-Design-Implementation (Analisis dan Desain Sistem).

3. Action Taking: System Prototype (Pembuatan dan Uji Sistem).

4. Evaluating: Evaluasi (loop lagi ke tahap action planning).

5. Specify Learning: Evaluasi dan Kesimpulan. 
Citec Journal, Vol. 5, No. 1, November 2017 - Januari 2018

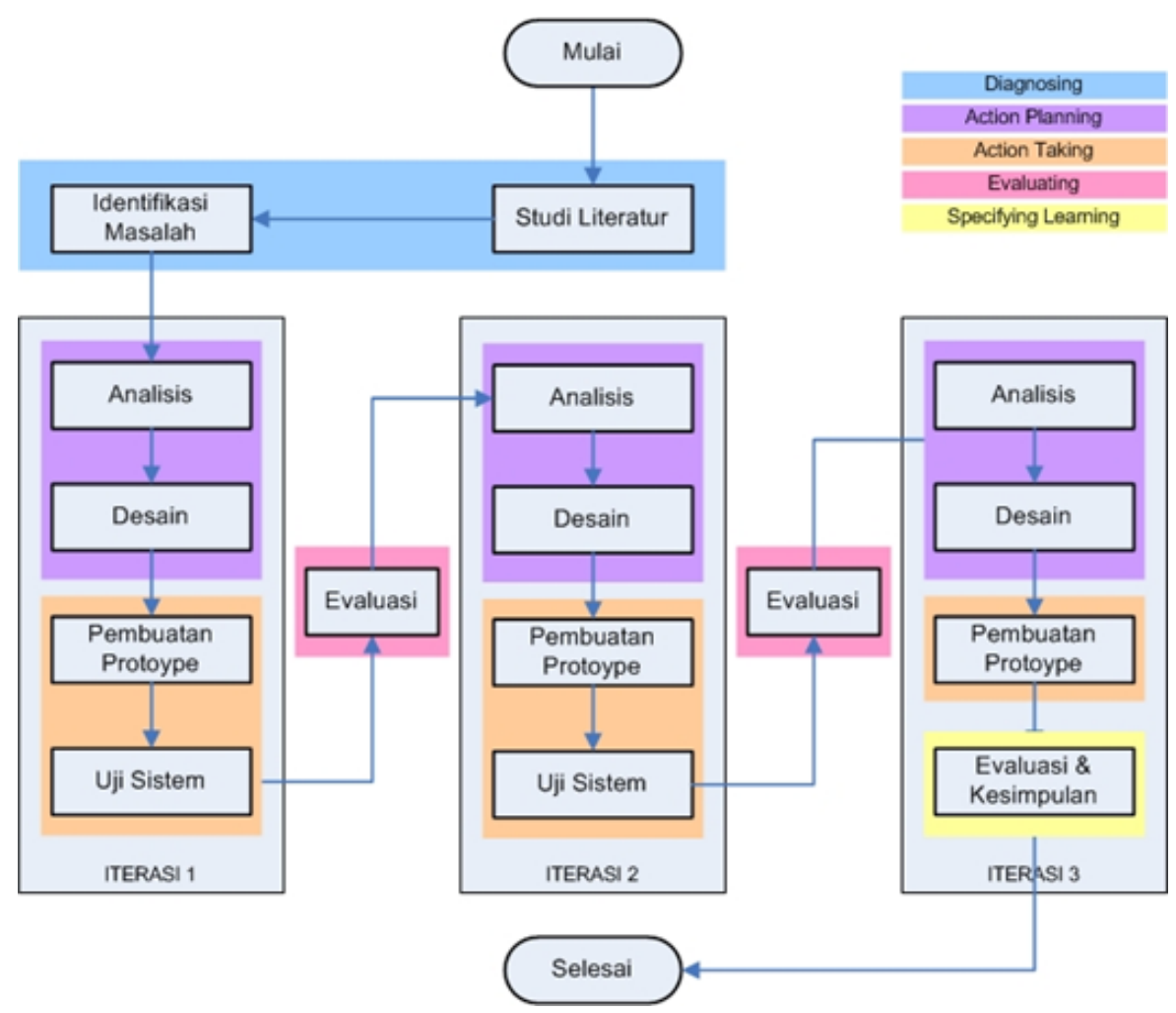

Gambar 1. Alur Penelitian

Kebutuhan fungsional untuk prototype sistem yang dibangun akan dijabarkan pada Tabel 1, yaitu sebagai berikut :

Tabel 1. Kebutuhan Fungsional

\begin{tabular}{|c|l|c|c|c|}
\hline \multirow{2}{*}{ No } & \multirow{2}{*}{ Kebutuhan Fungsional } & \multicolumn{3}{|c|}{ User } \\
\hline & & Siswa & Lembimjar & DTC \\
\hline 1 & Data Peserta & & & \\
\hline & - Input Data & & $\sqrt{ }$ & $\sqrt{ }$ \\
\hline & - Edit Data & $\sqrt{ }$ & $\sqrt{ }$ & $\sqrt{ }$ \\
\hline & - Delete Data & & $\sqrt{ }$ & $\sqrt{ }$ \\
\hline & - View Data & & $\sqrt{ }$ & $\sqrt{ }$ \\
\hline 2 & Psikotes & & & \\
\hline & - Mengerjakan Tes & $\sqrt{ }$ & & \\
\hline & - Input Tes & & & $\sqrt{ }$ \\
\hline & - Edit Tes & & & $\sqrt{ }$ \\
\hline & - Delete Tes & & & $\sqrt{ }$ \\
\hline & - View Tes & & & $\sqrt{ }$ \\
\hline 3 & Hasil & & & $\sqrt{ }$ \\
\hline & $-\quad$ View Report & $\sqrt{ }$ & & $\sqrt{ }$ \\
\hline
\end{tabular}

\subsection{Teori Kognitif}

Kognitif adalah kegiatan dan proses berkaitan dengan akuisisi, penyimpanan, pengambilan dan pengolahan pengetahuan.

"...cognitive psychology deals with how people perceive, learn, remember, and think about information.”. "....sebuah studi yang mempelajari tentang bagaimana seseorang menerima, mempelajari, mengingat, dan berfikir tentang suatu informasi [9].

"Cognitive psychology [is] the study of processes underlying mental events". "suatu studi terhadap proses-proses yang melandasi dinamika mental” (Solso, 2005) [10]. 
Aspek yang diukur ada 3 yaitu analitis, kreatif dan praktis. Pada tiap aspek tersebut terdapat subaspek yaitu figural, numerik dan verbal.

a. Analitis adalah kemampuan dalam menganalisa permasalahan, melakukan perencanaan dan membuat gagasan yang konkret.

b. Kreatif adalah kemampuan dalam menemukan sesuatu yang baru, mendesain, memodifikasi dan memunculkan ide yang inovatif.

c. Praktis adalah kemampuan dalam menggunakan konsep dan menyelesaikan permasalahan sehari-hari secara konkret.

\subsection{Teori Minat}

Teori original Holland mengalami modifikasi sebagai hasil dari penelitian ulang, hal ini terbatas pada lingkungan kerja pada masyarakat Amerika. John Holland mengatakan bahwa buku "Making Vocational Choices : A Theory of Vocational Personalities and Work Environments" merupakan perumusan teorinya yang kelima sejak karya tulisnya yang pertama pada tahun 1959. Teori Holland menge $\neg$ mukakan enam lingkungan okupasional dan enam tipe kepribadian [11].

Kualifikasi minat karir berikut ini dibuat berdasarkan teori Vocational Personality dari John Holland. Teori ini merupakan pendekatan yang paling banyak dipakai untuk membuat profil karir seseorang.

Menurut teori ini, terdapat enam tipe kepribadian vocational, dari ke-enam tipe ini, seseorang dapat memiliki profil pilihan karir yang unik sesuai dengan minat dan kepribadiannya.

Aspek yang diukur adalah 6 tipe dari hexagonal RIASEC, yaitu:
a. $\quad$ Realistic $=$ Tipe Pelaksana (Praktis)
b. Investigative $=$ Tipe Peneliti (Analitis)
c. Artistic $=$ Tipe Pencipta (Kreatif)
d. Social $=$ Tipe Sosial
e. Enterprising $=$ Tipe Komunikatif
f. $\quad$ Conventional $=$ Tipe Administratif

Prototype tes psikologi yang dibangun adalah siswa melakukan tes kognitif dan minat dan menghasilkan report berupa hasil pemeriksaan psikolog yang merupakan penggabungkan dari hasil tes kognitif dan hasil tes minat. Untuk tes kognitif menggunakan model multiple choice dan tes minat menggunakan model forced choice.

Tes pilihan ganda ( multiple choice test ) yaitu tes dimana setiap butir soalnya memiliki jumlah alternatif jawaban lebih dari satu. Biasanya terdapat dua sampai lima alternatif jawaban yang disuguhkan dan jumlah alternatif jawaban tersebut tidak boleh terlalu banyak karena akan sangat membingungkan dan juga sangat menyulitkan penyusunan butir soal [12].

Tes kognitif ini menggunakan penskoran tanpa koreksi. Tes ini berisi dari 54 soal dengan 5 pilihan jawaban dan salah sat jawaban benar, dan dibagi menjadi 3 bagian tes tiap aspek. Pembagian aspek dan subaspek pada tiap soal akan dijabarkan pada Tabel 2.

Tabel 2. Pembagian Aspek dan Subaspek Tes Kognitif

\begin{tabular}{|c|c|c|c|c|c|c|c|c|}
\hline No Soal & Aspek & Subaspek & No Soal & Aspek & Sub Aspek & No Soal & Aspek & Subaspek \\
\hline $1-6$ & Analitis & Verbal & $19-24$ & Kreatif & Verbal & $37-42$ & Praktis & Verbal \\
\hline $7-12$ & Analitis & Numerik & $25-30$ & Kreatif & Numerik & $43-48$ & Praktis & Numerik \\
\hline $13-18$ & Analitis & Figural & $31-36$ & Kreatif & Figural & $49-54$ & Praktis & Figural \\
\hline
\end{tabular}

Penskroan tanpa koreksi, yaitu penskoran dengan cara setiap butir soal dijawab benar mendapat nilai satu (tergantung bobot butir soal), sehingga jumlah skor yang diperoleh peserta didik adalah dengan menghitung banyaknya butir soal yang dijawab benar [13]. 
Berdasarkan model tersebut, untuk mendapatkan nilai skor tiap subaspek (verbal/ numerik/ figural) dapat menggunakan rumus persamaan ke-1 sebagai berikut :

Keterangan:

$$
\boldsymbol{N}_{\boldsymbol{S A}}=\boldsymbol{Q}-\boldsymbol{S}
$$

$\mathrm{N}_{\mathrm{SA}} \quad$ : Jumlah nilai subaspek

Q : Jumlah butir soal

$\mathrm{S} \quad$ : Jumlah soal yang dijawab salah

Setelah mendapatkan seluruh nilai dari subaspek, nilai tiap aspek dapat menggunakan rumus persamaan ke-2 sebagai berikut :

Keterangan:

$$
N_{A}=N_{S A 1}+N_{S A 2}+N_{S A 3}
$$

$\mathrm{N}_{\mathrm{A}} \quad$ : Jumlah Skor Tiap Aspek

$\mathrm{N}_{\mathrm{SA} 1}$ : Jumlah Skor Sub Aspek Pertama (Verbal)

$\mathrm{N}_{\mathrm{SA} 2}$ : Jumlah Skor Sub Aspek Kedua (Numerik)

Nsa3 : Jumlah Skor Sub Aspek Ketiga (Figural)

Kategori nilai yang dihasilkan dari skor total tiap aspek dibagi menjadi 5 kategori, yaitu :
1. Rendah
: Skor 1 sampai 3
2. Rata-Rata Bawah
: Skor 4 sampai 7
3. Sedang
: Skor 8 sampai 11
4. Rata-rata Atas
: Skor 12 sampai 15
5. Tinggi
: Skor 16 sampai 18

Setelah mendapatkan nilai dari tiap aspek, penilaian skor total tes kognitif dengan rumus persamaan ke-3, yaitu :

Keterangan:

$$
N=N_{A 1}+N_{A 2}+N_{A 3}
$$

N : Jumlah Skor Total

$\mathrm{N}_{\mathrm{A} 1} \quad$ : Jumlah Skor Aspek Pertama (Analitis)

$\mathrm{N}_{\mathrm{A} 2} \quad$ : Jumlah Skor Aspek Kedua (Kreatif)

$\mathrm{N}_{\mathrm{A} 3} \quad$ : Jumlah Skor Aspek Ketiga (Praktis)

Tes minat ini menggunakan metode paired comparison dengan model pilihan terarah (forced choice). Metode paired comparison merupakan model penskalaan dimana stimulus atau objek psikologis dibandingkan dalam suatu pasangan. Dalam metode ini subjek atau judgment diminta untuk memilih salah satu dari stimulus yang berpasangan. Stimulus yang dipilih adalah yang lebih menggambarkan karakeristik dirinya atau yang lebih disukai. Begitu pula jika ada stimulus yang tidak diminati, maka subjek tetap harus memilih salah satu yang lebih diminati. Karena ada kewajiban subjek untuk memilih, metode ini dikenal dengan forced choice [14].

Untuk tes minat berisi 30 soal. Tiap soal terdiri dari 2 pernyataan (stimulus) yang mewakili 2 aspek yang berbeda. Jawaban (aspek) yang dipilih akan mendapatkan skor 1 dan yang tidak dipilih mendapatkan skor 0. Pembagian aspek pada tiap soal akan dijabarkan pada Tabel 3.

Tabel 3. Pembagian Aspek Tes Minat

\begin{tabular}{|c|c|c|c|c|c|c|c|c|}
\hline \multirow{2}{*}{ No Soal } & \multicolumn{2}{|c|}{ Pilihan Jawaban } & \multirow{2}{*}{ No Soal } & \multicolumn{2}{|c|}{ Pilihan Jawaban } & \multirow{2}{*}{ No Soal } & \multicolumn{2}{|c|}{ Pilihan Jawaban } \\
\cline { 2 - 3 } \cline { 5 - 8 } & $\mathrm{A}$ & $\mathrm{B}$ & & $\mathrm{A}$ & $\mathrm{B}$ & & $\mathrm{A}$ & $\mathrm{B}$ \\
\hline 1 & $\mathrm{R}$ & $\mathrm{I}$ & 11 & $\mathrm{C}$ & $\mathrm{R}$ & 21 & $\mathrm{R}$ & $\mathrm{C}$ \\
\hline 2 & $\mathrm{~S}$ & $\mathrm{~A}$ & 12 & $\mathrm{~A}$ & $\mathrm{I}$ & 22 & $\mathrm{~S}$ & $\mathrm{I}$ \\
\hline 3 & $\mathrm{I}$ & $\mathrm{A}$ & 13 & $\mathrm{E}$ & $\mathrm{A}$ & 23 & $\mathrm{~S}$ & $\mathrm{R}$ \\
\hline 4 & $\mathrm{C}$ & $\mathrm{S}$ & 14 & $\mathrm{~A}$ & $\mathrm{R}$ & 24 & $\mathrm{E}$ & $\mathrm{S}$ \\
\hline 5 & $\mathrm{I}$ & $\mathrm{R}$ & 15 & $\mathrm{~A}$ & $\mathrm{C}$ & 25 & $\mathrm{I}$ & $\mathrm{E}$ \\
\hline 6 & $\mathrm{E}$ & $\mathrm{C}$ & 16 & $\mathrm{I}$ & $\mathrm{S}$ & 26 & $\mathrm{~S}$ & $\mathrm{C}$ \\
\hline
\end{tabular}




\begin{tabular}{|c|c|c|c|c|c|c|c|c|}
\hline \multirow{2}{*}{ No Soal } & \multicolumn{2}{|c|}{ Pilihan Jawaban } & \multirow{2}{*}{ No Soal } & \multicolumn{2}{|c|}{ Pilihan Jawaban } & \multirow{2}{*}{ No Soal } & \multicolumn{2}{|c|}{ Pilihan Jawaban } \\
\hline & $\mathrm{A}$ & B & & $\mathrm{A}$ & B & & $\mathrm{A}$ & $\mathrm{B}$ \\
\hline 7 & E & I & 17 & C & A & 27 & $\mathrm{R}$ & $\mathrm{E}$ \\
\hline 8 & A & $E$ & 18 & $\mathrm{R}$ & $\mathrm{S}$ & 28 & C & I \\
\hline 9 & $\mathrm{R}$ & $\mathrm{A}$ & 19 & I & C & 29 & $\mathrm{~A}$ & $\mathrm{~S}$ \\
\hline 10 & C & E & 20 & $S$ & E & 30 & $\mathrm{E}$ & $\mathrm{R}$ \\
\hline
\end{tabular}

Keterangan: "R” adalah aspek Realistic, "I” adalah aspek Investigative, “A” adalah aspek Artistic, "S” adalah aspek Social, "E” adalah aspek Enterprising dan "C” adalah aspek Conventional.

Tabel 4 berisi beberapa contoh kombinasi dari hasil tes kognitif dan tes minat berupa daftar jurusan eksakta yang akan menjadi rekomendasi jurusan bagi siswa.

Tabel 4. Tabel Kombinasi Jurusan Eksakta

\begin{tabular}{|c|l|l|l|l|}
\hline \multirow{2}{*}{ No Nama Jurusan } & \multirow{2}{*}{ Aspek Minat } & \multicolumn{2}{c|}{ Aspek Kognitif } \\
\cline { 4 - 5 } & & & \multicolumn{1}{|c|}{ Sedang } & \multicolumn{1}{|c|}{ Tinggi } \\
\hline 1 & Pendidikan Dokter & Pelaksana-Sosial & PF,AF & PV,AV \\
\hline 2 & Teknik Mesin & Pelaksana-Pencipta & AN, AF, PF & KN \\
\hline 3 & Teknik Elektro & Pelaksana-Pencipta & AN, AF, PF & KN \\
\hline 4 & Teknik Geologi & Pelaksana-Peneliti & AF, KF & PF \\
\hline 5 & Arsitektur & Pencipta-Pelaksana & KV, PN & KF \\
\hline 6 & Farmasi & Peneliti-Pelaksana & PV & AV, AN \\
\hline 7 & Kimia & Peneliti-Pelaksana & AV & AN \\
\hline 8 & Teknologi Pangan Hasil Pertanian & Peneliti-Pelaksana & AV, KN, PV & \\
\hline 9 & Kehutanan & Peneliti-Pelaksana & AN, AV, KF & PF \\
\hline 10 & Kedokteran Hewan & Peneliti-Sosial & AV & AF, PV \\
\hline 11 & Teknik Informatika & Pelaksana-Sosial & AV & AN, KN \\
\hline 12 & Teknik Kimia & Pelaksana-Administratif & PV & AN,AF \\
\hline 13 & Perencanaan Wilayah dan Kota & Pencipta-Pelaksana & AF, AV & PF, KF \\
\hline 14 & Matematika & Peneliti-Administratif & AV, KN & AN \\
\hline 15 & Fisika & Peneliti-Administratif & AV, KN & AN \\
\hline 16 & Teknologi Industri & Pelaksana-Administratif & AN, PN & AV, PV \\
\hline 17 & Teknik Sipil & Pelaksana-Pencipta & AF & AN, KF \\
\hline 18 & Ilmu keperawatan & Sosial-Administratif & AV, PF & PV \\
\hline 19 & Kesehatan Masyarakat & Sosial-Peneliti & AV, KV & PV \\
\hline 20 & Gizi Kesehatan & Sosial-Peneliti & KV, PV & AV, AN \\
\hline 21 & Pendidikan Matematika & Sosial-Administratif & KN, PN & AN \\
\hline 22 & Pendidikan Fisika & Sosial-Pelaksana & AV, KN & AN \\
\hline 23 & Teknik Pertambangan & Pelaksana-Peneliti & AF, KF, AN & PF \\
\hline 24 & Teknik Perminyakan & Pelaksana-Peneliti & AF, KF, PN & PF \\
\hline 25 & Statistika & Peneliti-Administratif & AV & AN, PN \\
\hline 26 & Fakultas Ilmu dan Teknologi Kebumian & Pelaksana-Peneliti & AF, KF & PF \\
\hline 27 & Teknik Lingkungan & Pencipta-Administratif & KV, PV & AV \\
\hline
\end{tabular}

Keterangan :

“A” adalah aspek Analitis, "K” adalah aspek Kreatif dan "P” adalah aspek Praktis.

"V” adalah subaspek Verbal, "N" adalah subaspek Numerik dan "F” adalah subaspek Figural.

Pada Tabel 4 berisi kombinasi untuk jurusan eksakta yang akan diperoleh dari hasil aspek minat dan aspek kognitif yang diukur. Namun jurusan yang ada di tabel hanya mencakup beberapa contoh jurusan saja, belum mencakup keseluruhan jurusan eksakta yang ada di Indonesia. 


\subsection{Rancangan Database}

Pada gambar 2 adalah tabel-tabel yang dibutuhkan dalam membangun protoype tes psikologi:

a. Tabel Peserta untuk menyimpan data dari peserta tes.

b. Tabel Login untuk akses masuk ke sistem menggunakan username dan password.

c. Tabel Ujian untuk menyimpan data pelaksanaan tes.

d. Tabel ujianminat dan ujiankognitif untuk menyimpan jawaban dari peserta.

e. Tabel soalminat dan soalkognitif untuk menyimpan soal-soal dari psikotes.

f. Tabel aspek untuk menyimpan tipe/ jenis aspek dari soal-soal kognitif.

g. Tabel bagian untuk menyimpan tipe/jenis subaspek dari soal-soal kognitif.

h. Tabel minat untuk menyimpan tipe/jenis aspek dari soal-soal minat.

i. Tabel penjurusan untuk menyimpan kriteria dari suatu jurusan.

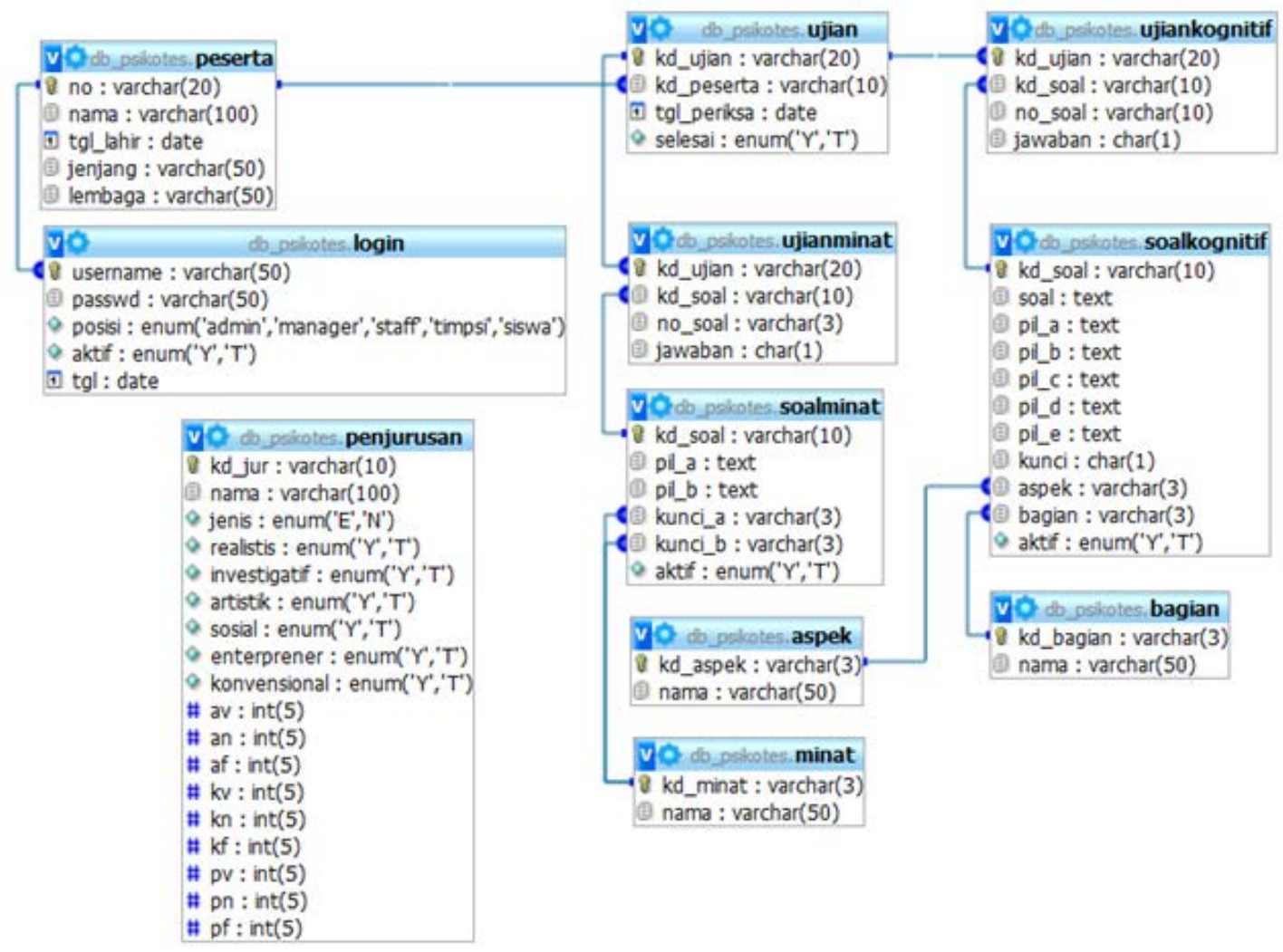

Gambar 2. Relasi Antar Tabel

\section{HASIL DAN PEMBAHASAN}

\subsection{Rancangan User Interface}

Prototype sistem yang dibuat adalah berdasarkan kebutuhan fungsional. Berikut ini beberapa halaman user interface yang sudah dirancang.

1. Halaman Peserta (Admin)

Gambar 3 adalah halaman untuk memuat daftar peserta (siswa) beserta 3 fungsi (aksi), yaitu sebelah kiri untuk reset login berupa proses mengganti password, aksi bagian tengah adalah untuk edit data peserta, dan aksi sebelah kanan untuk delete data peserta. 
TES PSIKOLOGI

HOME | USER | SISWA | TES | HASIL | LOGOUT (admin)

SISWA

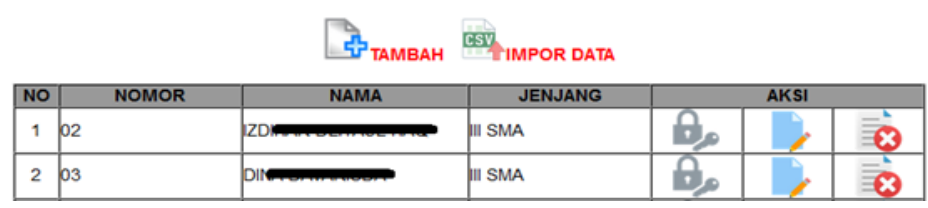

Gambar 3. Halaman Daftar Peserta

2. Halaman List Proses Tes Peserta (Admin)

Gambar 4 adalah halaman untuk memuat daftar proses tes peserta (siswa) dengan tambahan keterangan status pengerjaan tes. Apabila belum melakukan atau sedang melakukan akan muncul status "BELUM SELESAI", apabila sudah selesai mengerjakan akan muncul status “HASIL” yang berupa link menuju Hasil Pemeriksaan Psikologis (Report Hasil).

TES PSIKOLOGI

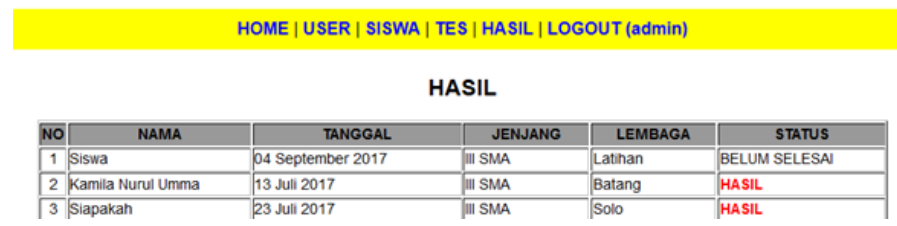

Gambar 4. Halaman List Proses Tes Peserta

\section{Halaman Tes (Siswa)}

Gambar 5 adalah halaman untuk memuat proses tes siswa. Pilihan jawaban menggunakan radio button dan diberikan batas waktu untuk pengerjaannya.

\section{BAGIAN D}

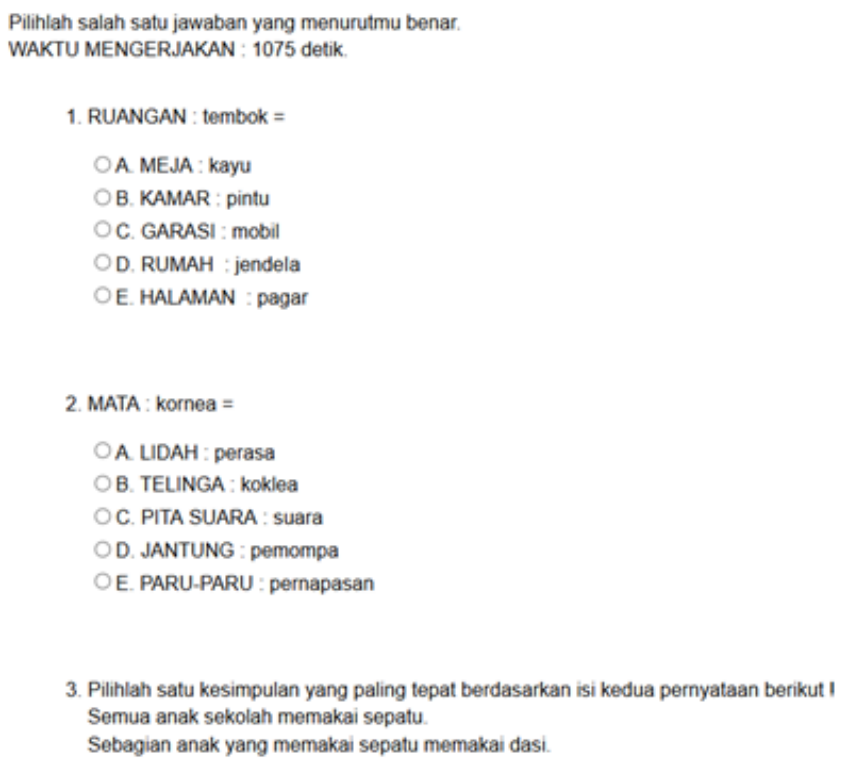

Gambar 5. Halaman Tes Peserta 
Citec Journal, Vol. 5, No. 1, November 2017 - Januari 2018

\section{Halaman Hasil Pemeriksaan Psikologis}

Gambar 6 adalah halaman report dari prototype yang dibangun. Berisi data siswa, hasil tes kognitif, tes minat lalu rekomendasi jurusan.

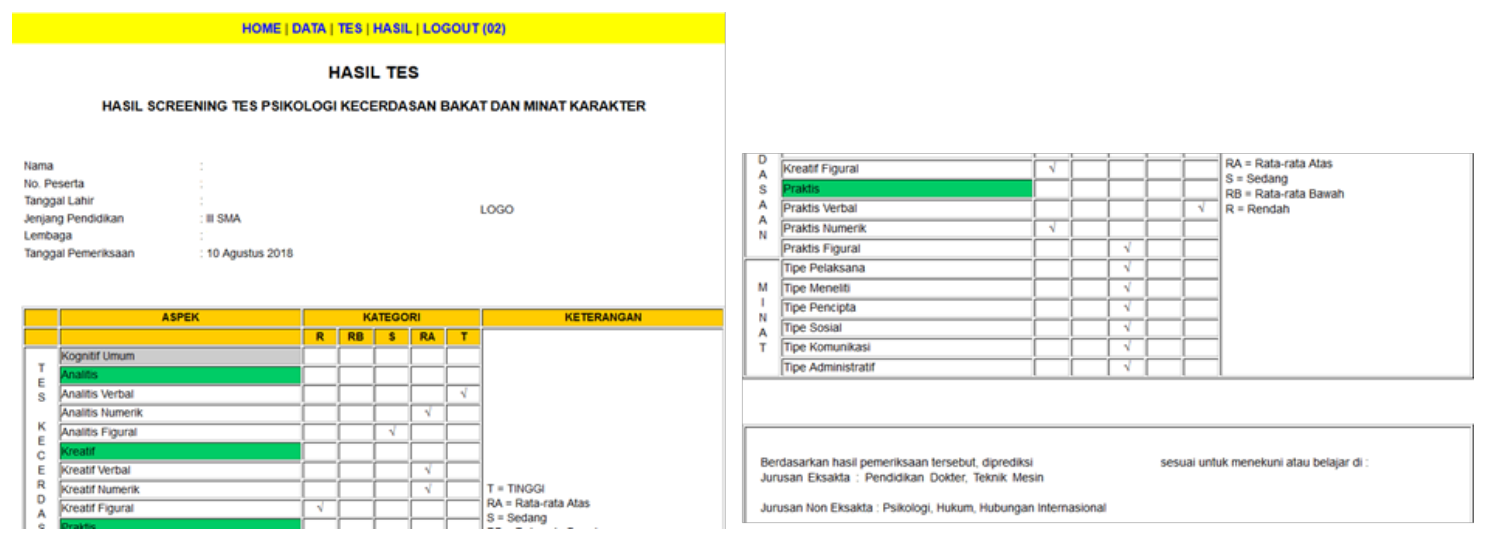

Gambar 6. Halaman Hasil Tes Peserta

\subsection{Pengujian Kebutuhan Fungsional}

Pengujian ini dilakukan menggunakan Black Box Testing untuk menguji fungsi-fungsi dari sistem apakah hasil dari sistem ini sesuai dengan kebutuhan yang diinginkan. Berikut daftar uji dijabarkan pada Tabel 5.

Tabel 5. Pengujian Fungsionalitas Sistem

\begin{tabular}{|c|l|l|l|c|}
\hline No & \multicolumn{1}{|c|}{ Nama Pengujian } & \multicolumn{1}{|c|}{ Rancangan } & \multicolumn{1}{c|}{ Hasil } & Keterangan \\
\hline 1 & $\begin{array}{l}\text { Menambahkan data } \\
\text { peserta }\end{array}$ & $\begin{array}{l}\text { Data peserta masuk } \\
\text { ke database sistem. }\end{array}$ & $\begin{array}{l}\text { Data peserta berhasil } \\
\text { ditambahkan ke database sistem. }\end{array}$ & Valid \\
\hline 2 & $\begin{array}{l}\text { Merubah data } \\
\text { peserta }\end{array}$ & Data peserta berubah. & Data peserta berhasil diubah. & Valid \\
\hline 3 & $\begin{array}{l}\text { Menghapus data } \\
\text { peserta }\end{array}$ & $\begin{array}{l}\text { Data peserta terhapus } \\
\text { dari. }\end{array}$ & $\begin{array}{l}\text { Data peserta berhasil dihapus dari } \\
\text { database sistem. }\end{array}$ & Valid \\
\hline 4 & $\begin{array}{l}\text { Menampilkan data } \\
\text { peserta }\end{array}$ & Data peserta tampil. & Data peserta berhasil ditampilkan. & Valid \\
\hline 5 & Proses tes. & $\begin{array}{l}\text { Peserta mengerjakan } \\
\text { tes. }\end{array}$ & $\begin{array}{l}\text { Peserta berhasil menyelesaikan } \\
\text { tes. }\end{array}$ & Valid \\
\hline 6 & $\begin{array}{l}\text { Menambahkan soal } \\
\text { tes. }\end{array}$ & $\begin{array}{l}\text { Data soal tes } \\
\text { bertambah. }\end{array}$ & $\begin{array}{l}\text { Soal tes baru berhasil } \\
\text { ditambahkan kedalam database. }\end{array}$ & Valid \\
\hline 7 & Merubah soal tes. & Data soal tes berubah. & Soal tes berhasil dirubah. & Valid \\
\hline 8 & Menghapus tes. & $\begin{array}{l}\text { Data soal tes } \\
\text { terhapus. }\end{array}$ & $\begin{array}{l}\text { Soal tes berhasil dihapuskan dari } \\
\text { database sistem. }\end{array}$ & Valid \\
\hline 9 & $\begin{array}{l}\text { Menampilkan data } \\
\text { soal tes. }\end{array}$ & Data soal tes tampil. & $\begin{array}{l}\text { Daftar soal tes berhasil } \\
\text { ditampilkan. }\end{array}$ & Valid \\
\hline 10 & $\begin{array}{l}\text { Menampilkan } \\
\text { Report }\end{array}$ & Report ditampilkan & Report berhasil ditampilkan. & Valid \\
\hline
\end{tabular}




\subsection{Pengujian Hasil Report Prototype}

Pengujian hasil report antara hasil dari pakar dengan hasil dari sistem bertujuan untuk mengetahui keakuratan dalam melakukan penilaian dari hasil psikotes yang dilakukan siswa. Keakurasian diukur berdasarkan hasil rekomendasi jurusan yang diberikan sistem sama atau tidak dengan pakar

Tabel 6. Pengujian Hasil Report Sistem

\begin{tabular}{|c|c|c|c|}
\hline No Uji & Hasil Pakar (Jurusan) & Hasil Prototype (Jurusan) & Status \\
\hline 01 & $\begin{array}{l}\text { Matematika, Kesehatan Masyarakat, Teknik } \\
\text { Nuklir }\end{array}$ & $\begin{array}{l}\text { Pendidikan Dokter, Gizi } \\
\text { Kesehatan }\end{array}$ & Valid \\
\hline 02 & Arsitekur, Gizi Kesehatan, Pemuliaan Tanah & Gizi Kesehatan & Valid \\
\hline 03 & Mtk, Kes Masy, Tk Nuklir & Mtk, Perencanaan Wil \& Kota & Valid \\
\hline 04 & Arsitektur, Gizi Kesehatan, Pemuliaan Tanah & Kehutanan, Arsitektur & Valid \\
\hline 05 & $\begin{array}{l}\text { Arsitektur, Teknik Industri, Kesehatan } \\
\text { Masyarakat }\end{array}$ & $\begin{array}{l}\text { Kesehatan Masyarakat, Teknik } \\
\text { Perminyakan }\end{array}$ & Valid \\
\hline 06 & Tk Mesin, Arsitekur, Tk Elektro & Teknik Sipil, Arsitektur & Valid \\
\hline 07 & Pend Dokter, Pend Bio, Giz Kes & Gizi Kesehatan & Valid \\
\hline 08 & $\begin{array}{l}\text { Kesehatan Masyarakat, Keperawatan, Pend } \\
\text { Keguruan }\end{array}$ & Farmasi, Kesehatan Masyarakat & Valid \\
\hline 09 & Tk. Industri, Tk. Ling, Pend Fis & Teknik Lingkungan & Valid \\
\hline 10 & Mtk, Kes Masy, Tk Nuklir & Statistika, Matematika & Valid \\
\hline 11 & $\begin{array}{l}\text { Kesehatan Masyarakat, Keperawatan, Pend } \\
\text { Keguruan }\end{array}$ & $\begin{array}{l}\text { Teknik Lingkungan, Kesehatan } \\
\text { Masyarakat }\end{array}$ & Valid \\
\hline 12 & Kimia, Kehutanan, Tek Kebumian & Kimia & Valid \\
\hline 13 & $\begin{array}{l}\text { Tek Industri, Tek Lingkungan, Pendidikan } \\
\text { Fisika }\end{array}$ & Pendidikan Fisika & Valid \\
\hline 14 & Kimia, Kehutanan, Tek Kebumian & Farmasi & Invalid \\
\hline 15 & $\begin{array}{l}\text { Kesehatan Masyarakat, Keperawatan, Pend } \\
\text { Keguruan }\end{array}$ & Kesehatan $\mathrm{N}$ & Valid \\
\hline 16 & $\begin{array}{l}\text { Keperawatan, Statistika, Pendidikan } \\
\text { Matematika }\end{array}$ & Pendidikan Matematika & Valid \\
\hline 17 & Arsitektur, Tk Mesin, Tk Elektro & Arsitektur, Tk Mesin, Tk Elektro & Valid \\
\hline 18 & $\begin{array}{l}\text { Tek Lingkungan, Tk Informatika, Pendidikan } \\
\text { Kimia }\end{array}$ & $\begin{array}{l}\text { Teknik Informatika, Pendidikan } \\
\text { Kimia }\end{array}$ & Valid \\
\hline 19 & Mtk, Kes Masy, Tk Nuklir & Mtk, Kes Masyarakt & Valid \\
\hline 20 & Mtk, Kes Masy, Tk Nuklir & Kedokteran Hewan, Kes Masy & Valid \\
\hline 21 & $\begin{array}{l}\text { Tk Lingkungan, Tk Informatika, Pendidikan } \\
\text { Kimia }\end{array}$ & - & Invalid \\
\hline 22 & Keperawatan, Statistika, Pend Matematika & - & Invalid \\
\hline 23 & Arsitketur, Tk Industri, Kes Masy & Tk Geologi, Tk Mesin, Tk Elektro & Valid \\
\hline 24 & Pend Dokter, Pend Bio, Gizi Kes & Pend Fisika & Valid \\
\hline 25 & Mtk, Kes Masy, Tk Nuklir & Matematika, Fisika & Valid \\
\hline 26 & Pend Dokter, Pend Bio, Giz Kes & Pend Dokter, Giz Kes, Tk Kimia & Valid \\
\hline 27 & $\begin{array}{l}\text { Kes Masy, Keperawatan, Pendidikan } \\
\text { Keguruan }\end{array}$ & Kimia & Invalid \\
\hline 28 & Kimia, Giz Kes, Tek Kebumian & Farmasi & Invalid \\
\hline 29 & Arsitektur, Giz Kesehatan, Pemuliaan Tanah & - & Invalid \\
\hline 30 & Keperawatan, Statistika, Pend Mtk & Matematika & Valid \\
\hline
\end{tabular}

Keterangan:

Valid

Invalid

: Hasil yang diperoleh sistem akurat dengan hasil dari pakar.

: Hasil yang diperoleh sistem tidak akurat dengan hasil dari pakar. 
Pada Tabel 6, terdapat hasil dari perbandingan report 30 siswa sebagai sebagai berikut:

a. Valid : hasil jurusan yang sama, pada no uji 02-13, 15-20, 25 \& 26.

b. Valid : hasil jurusan berbeda tapi jenis ilmu yang sama, pada no uji 01, 23, $24 \& 30$.

c. Invalid : hasil jurusan yang berbeda dan cabang ilmu yang berbeda, pada no uji 14, 27 \& 28.

d. Invalid : hasil jurusan tidak muncul pada no uji 21,22 \& 29.

Dari hasil menggunakan data dari 30 siswa yang telah disajikan di Tabel 6, terdapat 24 siswa yang report-nya tergolong valid, sehingga keakuratan sistemnya mencapai $80 \%$. Adapun faktor-faktor yang mempengaruhi mengapa ada hasil rekomendasi siswa tidak muncul atau invalid, yaitu sebagai berikut:

a. Nilai dari hasil kognitif dari siswa tidak masuk kategori rekomendasi jurusan.

b. Masih terbatasnya jumlah jurusan yang ada di database.

Kelebihan prototype sistem ini adalah:

a. Lebih lengkap karena mencakup aspek minat dan kognitif siswa. Dengan menggabungkan minat dan kognitif (bakat) siswa, mendapatkan rekomendasi jurusan yang lebih tepat sesuai kondisi siswa dibandingkan hanya menggunakan tes minat atau tes bakat/ inteligensi.

b. Secara konsep, teori Holland sangat cocok untuk siswa sekolah, karena minat tersebut diukur dari kepribadian. Sedangkan tes minat RMIB mengukur minat berdasarkan sikap terhadap suatu pekerjaan dan kurang cocok untuk siswa.

c. Menggunakan teori Sternberg lebih cocok karena dapat mengetahui kecenderungan bakat siswa (analitis-kreatif-praktis). Sedangkan tes inteligensi (IQ) hanya mengukur kecerdasan akademik (analitis) dan hasilnya dapat berubah.

Kelemahan prototype sistem ini adalah:

a. Perlu waktu dan usaha yang lebih bagi tim psikologi untuk judgment kombinasi jurusan.

b. Secara konsep, teori Sternberg lebih sesuai untuk subjek yang mempunyai kecerdasan di atas rata-rata, karena hanya mengukur aspek-aspek dengan kemampuan memori dan analisa.

c. Pada teori Holland, bisa memungkinkan untuk siswa melakukan faking atau memalsukan pilihan. Misalnya subjek seharusnya memilih pernyataan yang lebih mencerminkan dirinya, namun subjek memilih pernyataan yang menurutnya apabila memilih pernyataan tersebut maka orang lain akan melihat dirinya baik.

d. Dibutuhkan sarana penunjang tes untuk memenuhi kebutuhan jumlah siswa yang banyak.

\section{KESIMPULAN}

Dari hasil perbandingan report (rekomendasi jurusan) dari hasil pakar dan hasil sistem, dapat disimpulkan bahwa:

1. Prototype ini sudah berjalan dengan baik dan layak untuk digunakan.

2. Pengambil keputusan (siswa) dapat menggunakan report atau hasil pemeriksaan psikologis ini dalam pengambilan keputusan untuk menentukan jurusan di perguruan tinggi.

3. Pihak lembaga psikologi (DTC) dapat mengurangi pemakaian tenaga konseling dan dapat mengganti peran konseling dengan hasil pemeriksaan psikologis ini.

\section{SARAN}

Saran bagi peneletian selanjutnya adalah melengkapi jurusan-jurusan yang belum ada (termasuk jenis-jenis jurusan non eksakta) dan menambahkan pilihan lokasi kota maupun perguruan tinggi yang menjadi keinginan siswa dan menjadi tambahan hasil rekomendasi untuk siswa di dalam report sistem. 
ISSN: 2460-4259

Tahap penilaian atau hasil rekomendasi ini masih sebatas dari aspek psikologis siswa, belum dikombinasikan dengan hasil akademik siswa di sekolah maupun di lembaga bimbingan lain. Perlu adanya tambahan informasi atau saran pengganti konseling pada report apabila siswa tersebut mempunyai nilai kognitif yang kurang dibandingkan dengan jurusan yang dia inginkan.

\section{DAFTAR PUSTAKA}

[1] Andayati. D, 2012, Sistem Pakar Dalam Bidang Psikologi, Prosiding Seminar Nasional Aplikasi Sains \& Teknologi (SNAST) Periode III, Yogyakarta, 3 Nov 2012.

[2] Pratiwi. D., 2014, Decision Support System to Majoring High School Student Using Simple Additive Weighting Method, International Journal of Computer Trends and Technology (IJCTT), Vol. 10, No. 3, Hal 153 - 159.

[3] Rohman, N., Darmawan. Y. M., 2013, Aplikasi Test Minat dan Bakat Penerimaan Siswa Baru pada SMK TI Garuda Nusantara Cimahi Menggunakan Visual Basic.Net, Jurnal Computech \& Bisnis, Vol. 7, No.1, Hal $13-18$.

[4] Yulianto., Setiadi, A., Adnandi, M. A., Wibowo, S. T., Pratama, D., Rizky, A. B., 2015, Analisa Sistem Pakar untuk Identifikasi Kepribadian Siswa Menggunakan Algoritma Fuzzy pada Siswa SLTA, Seminar Nasional Teknologi Informasi dan Multimedia 2015, Yogyakarta, 6-8 Februari 2015.

[5] Saputro, D. A. H., 2013, Peta Minat Vokasional Siswa SMA dan SMK di Kota Salatiga Berbasis Teori Holland, Tesis, Magister Sains Psikologi, Universitas Muhammadiyah Surakarta.

[6] Surianti., Wijaya, E., 2017, Rancangan Sistem Pakar Psikotes untuk Penyeleksian Penerimaan Karyawan pada STMIK TIME Medan, Jurnal Times Technology Informatics \& Computer Systems, Vol. 6, No. 2, Hal 69 - 78.

[7] Ahyuna., Irmawati., 2016, Perancangan Aplikasi Tes IQ Siswa untuk Pertimbangan Pemilihan Jurusan dengan Metode Forward Chaining, Citec Journal, Vol. 3, No. 2, Hal 102112.

[8] Kasma, P. F., 2013, Menentukan Kecenderungan dan Karakter Seseorang dengan Sistem Pakar Menggunakan Tekhnik Backward Chaining Menerapkan Prinsip Experiental Learning, Eksplora Informatika, Vol. 2, No. 2, Hal 159 - 168.

[9] Sternberg. R. J., 2003, Cognitive Psychology (3rd ed.) Fort Worth, Harcourt Brace, Texas.

[10] Solso, R. L., Maclin, O. H., Maclin, M. K., 2009, Psikologi Kognitif (Edisi 8). Erlangga, Jakarta.

[11] Holland. J. L., 1985, Making Vocational Choice; A Theory of Vocational Personality \& Work Environment. Prentice - Hall, New Jersey.

[12] Khasanah, T. N., 2015, Instrumen Tes Pilihan Ganda, http://oktobernursenja.blogspot. com/2015/05/instrumen-tes-pilihan-ganda.html, diakses tanggal 19 Agustus 2018.

[13] Vionita, E., 2015, Penskoran, https://www.academia.edu/16874042/PENSKORAN, diakses tanggal 19 Agustus 2018.

[14] Setiawati. F. A., 2012, Paired Comparison sebagai Sebuah Model Instrumen untuk Menggali Karakteristik Nonkognitif Siswa, 1st International Seminar On Guidance and Counseling, Yogyakarta, 8-9 September 2012. 